\title{
CARACTERIZAÇÃO BROMATOLÓGICA DA MANIPUEIRA PARA UTILIZAÇÃO NA ALIMENTAÇÃO OVINOS NO EXTREMO SUL DA BAHIA
}

\author{
AUTOR: MARCIO GUILHERME SANTOS RODRIGUES \\ CO-AUTOR/ORIENTADOR: LUANNA CHACARA PIRES
}

\begin{abstract}
Resumo: Objetivou-se neste trabalho comparar o desenvolvimento ponderal em um rebanho de ovinos mestiços de corte na Fazenda Olhos d'água em Alcobaça, Bahia. Assim como também, realizar a análise físico-química da água manipueira de farinheiras localizadas em Alcobaça, Bahia. Foram realizadas coletas de dados de peso corporal, escore corporal e medidas biométricas dos ovinos. Para manipueira analisou-se amostras da água de manipueira de farinheiras e essas amostras foram subdivididas em três e analisadas 0, 5, 6, 10 e 15 dias após recebimento com a finalidade de analisar os parâmetros físico-químicos da água de manipueira no decorrer da fermentação em 15 dias. Os resultados mostraram que o acompanhamento de medidas biométricas pode ser ferramenta importante para o produtor na formação de lotes mais homogêneos, na tomada de decisões de manejo e na seleção de animais superiores, visto que estas informações podem ser um indicador do futuro potencial produtivo dos animais. A raça Santa Inês obteve melhor desempenho corporal e produtivo devido sua maior adaptação ao clima da região. Porém, ainda assim, se encontra com reduzido desempenho. $O$ rebanho da fazenda necessita de uma suplementação de acordo com a exigência nutricional de cada categoria animal. A criação de ovinos da White Dorper em sistema extensivo, limita o crescimento dos animais. Mais estudos da manipueira da variedade Caravelas são preconizados para que se possa propor seu uso para alimentação animal.
\end{abstract}

Palavras-chave: Ovis aries, subproduto da mandiocultura, Desempenho produtivo. 